\title{
Reaction of human small intestine to an intraluminal tube and its importance in jejunal perfusion studies
}

\author{
G. C. $\operatorname{COOK}^{1}$ AND R. H. CARRUTHERS \\ From the Departments of Medicine and Surgery, The University of Zambia, Lusaka, Zambia
}

SUMMARY A double-lumen tube with a mercury weight attached to its distal end was positioned in the small intestine of six subjects who were to undergo an elective laparotomy. The tube and the technique for its localization were exactly similar to those used in previous intestinal perfusion experiments.

Marked 'concertinaing', or gathering of the small intestine proximal to the mercury weight, was seen at laparotomy in all six subjects. The ratio between the mean intestinal length from the mercury weight to the ligament of Treitz after removal of the tube to that with the tube in situ was $3.0(2.5$ 3.8). Mean total jejuno-ileal length was $421(320-521) \mathrm{cm}$. In five of the six subjects the distal end of the tube was more than half way between the ligament of Treitz and the ileo-caecal valve although it was only 100-120 (mean 108) $\mathrm{cm}$ from the incisor teeth.

Segmental perfusion studies of the human jejunum involve a much longer length of small intestine than is generally assumed - by a factor of approximately 3. Such studies assess absorption rates over a substantial proportion of the small intestine and are not confined to a short segment of proximal jejunum. The nutritional significance of such studies in which amino acids, peptides, and carbohydrates are investigated is increased. Studies designed to measure absorption rates from the ileum should be treated with caution as part or all of the perfusion segment may be past the ileo-caecal valve.

Gathering or 'concertinaing' of the small intestine as a response to an intraluminal tube is well recognized (Hirsch, Ahrens, and Blankenhorn, 1956; Shields, 1972). Double or triple-lumen tubes are frequently used for estimating absorption rates of amino acids, peptides, carbohydrates, electrolytes, and water from the human small intestine, and

${ }^{1}$ Correspondence and reprint requests to Professor G. C. Cook, Department of Medicine, The University of Zambia, P.O. Box R.W. 110, Lusaka, Zambia.

Received for publication 23 April 1974. results are expressed as rate per unit length-usually $30 \mathrm{~cm}$. The present investigation was undertaken to quantitate the importance of 'concertinaing' in the interpretation of intestinal perfusion studies.

\section{Subjects and Methods}

Table I summarizes the clinical details of the six subjects who were studied. They were all undergoing an elective laparotomy at the University Teaching

\begin{tabular}{|c|c|c|c|c|c|}
\hline Subject No. & Sex & Age (yr) & Nationality & Body Weight $(\mathrm{kg})$ & Clinical Diagnosis \\
\hline $\begin{array}{l}1 \\
2\end{array}$ & $\begin{array}{l}\mathbf{M} \\
\mathbf{F}\end{array}$ & $\begin{array}{l}35 \\
32\end{array}$ & $\begin{array}{l}\text { Chewa } \\
\text { Kunda }\end{array}$ & $\begin{array}{l}68 \\
46\end{array}$ & $\begin{array}{l}\text { Left ureteric calculus } \\
\text { Carcinoma of urinary bladder; Schistosoma } \\
\text { haematobium infestation }\end{array}$ \\
\hline $\begin{array}{l}3 \\
4 \\
5\end{array}$ & $\begin{array}{l}\mathbf{M} \\
\mathbf{M} \\
\mathbf{F}\end{array}$ & $\begin{array}{l}44 \\
28 \\
37\end{array}$ & $\begin{array}{l}\text { Swaka } \\
\text { English } \\
\text { Tonga }\end{array}$ & $\begin{array}{l}54 \\
69 \\
59\end{array}$ & $\begin{array}{l}\text { Duodenal ulcer } \\
\text { No abnormality (diagnostic laparotomy) } \\
\text { Carcinoma of urinary bladder; Schistosoma } \\
\text { haematobium infestation }\end{array}$ \\
\hline
\end{tabular}

Table I Clinical details of the six subjects investigated 'Brelsford (1965) 


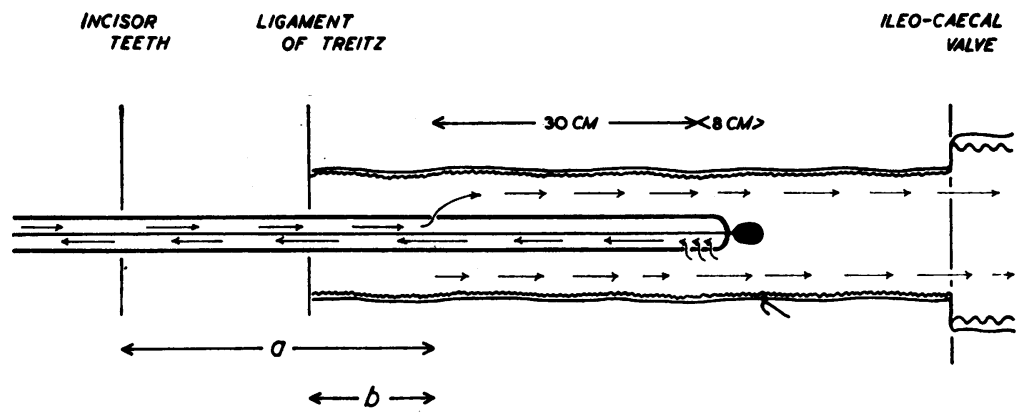

Fig 1 Diagram of the double-lumen tube. Measurement a was a direct measurement of tube length, and $\mathrm{b}$ was made from the abdominal radiograph. Measurements $\mathrm{x}_{1}, \mathrm{x}_{2}$, and $\mathrm{y}$ were made at laparotomy (see text)

Hospital, Lusaka, and the purpose of the present investigation was explained. None was malnourished. They had not previously been investigated.

A double-lumen tube (Portex MLT/B) (external diameter $4.2 \mathrm{~mm}$ ) was swallowed on the evening before the laparotomy (Cook, 1971a and b, 1974a) (fig 1). The mercury weight was approximately $50 \mathrm{~g}$. The tube was anchored with adhesive strapping applied to the face; the distal pole of the mercury weight was $100-120$ (mean 108) $\mathrm{cm}$ from the incisor teeth, and the infusion opening 62-82 (mean 70) $\mathrm{cm}$ from the incisor teeth $(a)$. Sips of water were permitted overnight. Between 14 and $18 \mathrm{hr}$ later the position of the tube was localized by an abdominal radiograph taken with the subject in the supine position. The distance between the proximal opening and the ligament of Treitz (cm) was measured on the radiograph with thread and reduced by a factor of $20 \%$ as an approximation for magnification; the resulting estimate was designated $b$ and was 8 to 31 (mean 15) $\mathrm{cm}$. The distance of the distal pole of the mercury weight from the ligament of Treitz is therefore $b+$ the length of the perfusion segment of the tube $(30 \mathrm{~cm})+$ the distance between the distal opening of the tube and distal pole of the mercury weight $(8 \mathrm{~cm})$, ie, $(b+38) \mathrm{cm}$.

Anaesthetics were given by $\mathrm{Dr} D$. M. Nagle. Atropine and morphine were given for premedication, and thiopentone sodium for induction. In cases 1 and 3 gallamine triethiodide was used for muscle paralysis and ventilation was with $\mathrm{N}_{2} \mathrm{O}$ and oxygen; in cases $2,4,5$, and 6 spontaneous breathing was maintained and $\mathrm{N}_{2} \mathrm{O}$, oxygen, and halothane were used. Immediately after the abdominal cavity was opened, the mercury weight was located and its position secured by a loose proximal suture around the small intestine. A black silk suture was tied subserosally over the distal pole of the mercury weight. By applying a length of black silk to the nonmesenteric border of the small intestine, the distance between the suture and ligament of Treitz $\left(x_{1}\right)$ was estimated in triplicate. Following withdrawal of the tube, the measurement was repeated in triplicate $\left(x_{2}\right)$. By a similar technique the distance from the suture to the ileo-caecal valve $(y)$ was estimated, also in triplicate. Table II summarizes results of reproducibility of the triplicate measurements.

\begin{tabular}{llcl}
\hline Measurement & $\begin{array}{l}\text { Mean length } \\
(\mathrm{cm})\end{array}$ & $S D^{1}$ & $\begin{array}{l}\text { Coefficient of } \\
\text { Variation (\%) }\end{array}$ \\
\hline $\begin{array}{llcl}\text { Distal end of mercury weight } \\
\text { to ligament of Treitz }\left(x_{1}\right)\end{array}$ & 81.8 & 6.4 & 7.8 \\
$\begin{array}{l}\text { Distal end of mercury weight } \\
\text { to ligament of Treitz }\left(x_{2}\right)\end{array}$ & 242.7 & 17.5 & 7.2 \\
$\begin{array}{l}\text { Distal end of mercury weight } \\
\text { to ileo-caecal valve }(y)\end{array}$ & 179.4 & 18.3 & 10.2 \\
\hline
\end{tabular}

Table II Reproducibility of three measurements of intestinal length made at laparotomy in the six subjects

${ }^{1}$ The SD values are calculated as described by Cook (1971a; 1972)

\section{Results}

In all subjects marked concertinaing of the small intestine was noted. Figure 2 shows the appearance in subject no. 6. In two subjects (nos. 1 and 4) multiple small intussusceptions were noted immediately after withdrawal of the tube. In all of them the mercury weight seemed to be in the ileum, although biopsy specimens were not obtained.

Figure 3 summarizes the results of the mean intestinal measurements. The mean ratio $x_{2} / x_{1}$ is 3.0 $(2 \cdot 5-3 \cdot 8)$, and the mean ratio $x_{2} /(b+38)$ is $4 \cdot 6$ (3.3-6.4). The differences between the means for $x_{2}$ and $x_{1}(\mathrm{t}=8.72 ; \mathrm{df}=5 ; \mathrm{P}<0.001)$, and $x_{2}$ and $(b+38)(\mathrm{t}=8.46 ; \mathrm{df}=5 ; \mathrm{P}<0.001)$ are significant by the paired $t$ test. The mean values for $x_{1}, x_{2}$, and $y$ in the English subject (no. 4) were 84, 322, and $163 \mathrm{~cm}$ respectively. 


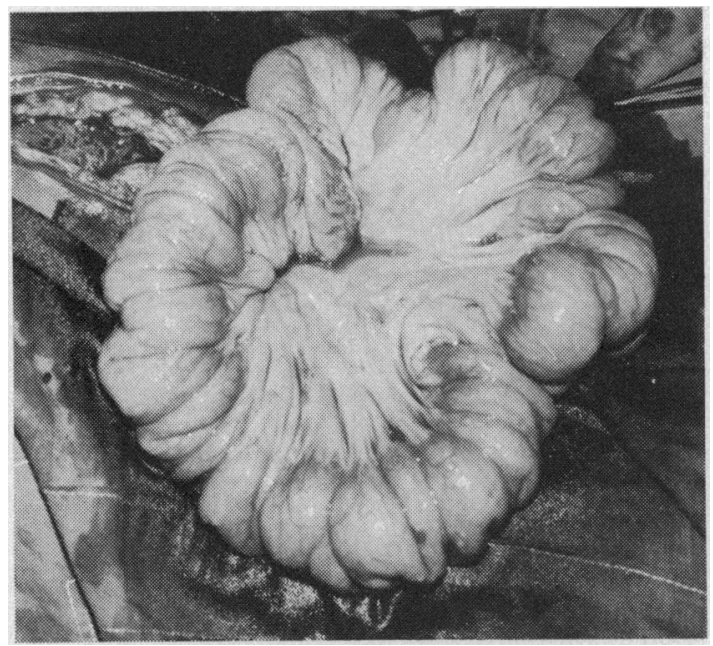

Fig 2 Marked concertinaing of the small intestine proximal to the mercury weight shown at laparotomy in subject no. 6

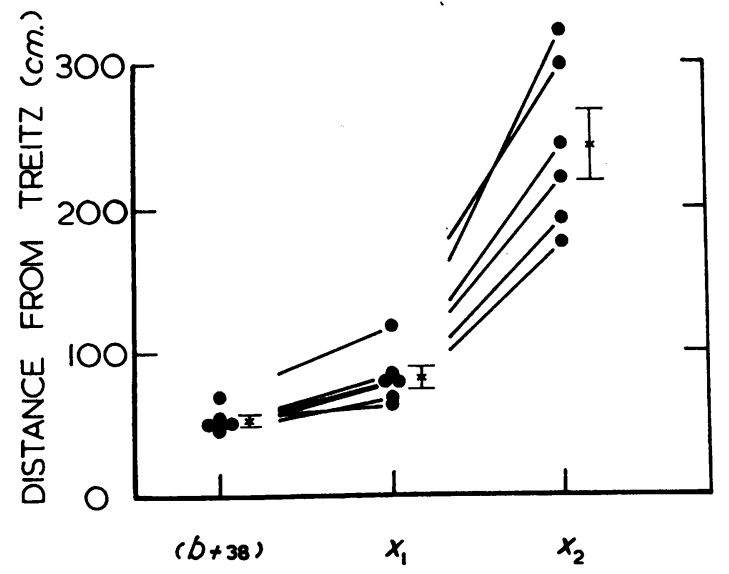

Fig 3 Summary of results for $(\mathrm{b}+38), \mathrm{x}_{1}$ and $\mathrm{x}_{2}(\mathrm{~cm})$ in the six subjects. The means $\pm 1 . S E M$ are shown.

The mean distance between the distal end of the mercury weight and the ileo-caecal valve $(y)$ was 179 $(75-276) \mathrm{cm}$. The mean total length of small intestine after removal of the tube $\left(x_{2}+y\right)$ was 421 (320-521) cm.

\section{Discussion}

The study clearly shows that with a small intestinal perfusion tube with a fixed proximal end marked concertinaing (or gathering) of intestine over the tube takes place. The extent of the concertinaing seems to be best expressed as the ratio $x_{2} / x_{1}$ in which both measurements were made at laparotomy over a short space of time, approximately $15 \mathrm{~min}$, with the subject under the same anaesthetic; the mean length of intestine which would have been perfused is then three times the length of the perfusion segment of the tube, ie, $30 \mathrm{~cm}$. It is impossible to estimate the actual mucosal area perfused and also the extent to which the perfusing fluid penetrates the crevices of the tightly concertinaed intestine. Results of previous perfusion studies in the same subject using an exactly similar tube suggest that alteration in the perfused mucosal area is minimal over a perfusion period of three to four hr (Cook, 1971b, 1973a, 1974a and b). There is probably greater intersubject variation in the perfused mucosal area but in practice that also seems to be very limited (Cook, 1971a, 1973b, 1974a).

Previous studies have indicated a significant correlation between $D$-xylose excretion after an oral load and the small intestinal absorption rate of glucose (Cook 1971a, unpublished observation) and D-xylose (Corcino, Maldonado, and Klipstein, 1973). The present finding explains that observation as the length perfused represents a substantial proportion of the small intestinal mucosal surface area and not merely a $30-\mathrm{cm}$ segment. The present finding therefore increases the nutritional importance of small-intestinal absorption studies of amino acids, peptides, and carbohydrates which were previously believed to apply to a short segment, eg, $30 \mathrm{~cm}$, of proximal jejunum. Studies in which $K_{t}$ and $V_{\max }$ values have been calculated for a $30-\mathrm{cm}$ segment of proximal jejunum should be re-evaluated; a much larger absorptive area has in fact been studied. Previous studies of absorption rates in the ileum should also be re-evaluated as it seems likely that in some cases part or all of the perfused segment was in fact in the colon.

The site of intestinal biopsy with a small intestinal biopsy capsule, when the proximal end of the tube is fixed, must be critically evaluated in the light of the present finding. It seems possible that some biopsy specimens which have been assumed to be from the proximal jejunum have in fact been taken from the distal jejunum or even the ileum.

The effect of altering the size of the weight on the extent of concertinaing has not been evaluated in the present study; it seems possible that that may have some importance.

The mean estimate of small intestinal length in the present study is greater than that reported by Hirsch, Ahrens, and Blankenhorn (1956). Using a technique with a $2.1 \mathrm{~mm}$ diameter tube which was not fixed, they estimated that in 10 subjects in vivo the mean jejuno-ileal length was $261(206-318) \mathrm{cm}$; they claimed that concertinaing or gathering was negligible or nonexistent. 
We thank Mr James Tembo for explaining the procedure to the subjects, and the Reverend W. $\mathrm{H}$. Woodhouse for financial support. Mr M. A. Ansary kindly took the photograph for figure 2 .

\section{References}

Brelsford, W. V. (1965). The Tribes of Zambia, 2nd ed. Government Printer, Lusaka.

Cook, G. C. (1971a). Glucose absorption kinetics in Zambian African patients with and without systemic bacterial infections. Gut, 12, 1001-1006.

Cook, G. C. (1971b). Impairment of glycine absorption by glucose and galactose in man. J. Physiol. (Lond.), 217, 61-70.

Cook, G. C. (1972). Effect of intraluminal concentrations on the impairment of glycine absorption by glucose in the human jejunum. Clin. Sci., 42, 525-534.
Cook, G. C. (1973a). Independent jejunal mechanisms for glycine and glycylglycine transfer in man in vivo. Brit. J. Nutr., 30, 13-19.

Cook, G. C. (1973b). Increased glycine absorption rate associated with acute bacterial infections in man. Brit. J. Nutr., 29, 377-386.

Cook, G. C. (1974a). Some factors influencing absorption rates of the digestion products of protein and carbohydrate from the proximal jejunum of man and their possible nutritional implications. Gut, 15, 239-245.

Cook, G. C. (1974b). Effect of glycylglycine and glycine on jejunal absorption rate of L-histidine in man in vivo. J. Physiol. (Lond.), 237, 187-194.

Corcino, J. J., Maldonado, M., and Klipstein, F. A. (1973). Intestinal perfusion studies in tropical sprue. 1. Transport of water, electrolytes, and D-xylose. Gastroenterology, 65, 192-198.

Hirsch, J., Ahrens, E. H., Jr., and Blankenhorn, D. H. (1956). Measurement of the human intestinal length in vivo and some causes of variation. Gastroenterology, 31, 274-284.

Shields, R. (1972). Contribution to discussion, In Transport across the intestine, Edited by W. L. Burland and P. D. Samuel, p. 75. Churchill Livingstone, Edinburgh and London. 